\title{
Water quality assessment and hydrochemical characterization of Zamzam groundwater, Saudi Arabia
}

\author{
Fahad N. Al-Barakah ${ }^{1}$ Abdurahman M. Al-jassas ${ }^{2} \cdot$ Anwar A. Aly $^{1,3}$
}

Received: 18 November 2016/Accepted: 21 February 2017/Published online: 8 March 2017

(C) The Author(s) 2017. This article is published with open access at Springerlink.com

\begin{abstract}
This study focuses on chemical and microbial analyses of 50 Zamzam water samples, Saudi Arabia. The soluble ions, trace elements, total colony counts, total coliform group, and E. coli were determined and compared with WHO standards. The obtained results indicated that the dissolved salts, soluble cations and anions, $\mathrm{Pb}, \mathrm{Cd}, \mathrm{As}$, $\mathrm{Zn}, \mathrm{Cu}, \mathrm{Ni}, \mathrm{Co}, \mathrm{Fe}, \mathrm{Mn}, \mathrm{Cr}, \mathrm{PO}_{4}{ }^{3-}, \mathrm{NO}_{2}{ }^{-}, \mathrm{Br}^{-}, \mathrm{F}^{-}, \mathrm{NH}_{4}{ }^{+}$, and $\mathrm{Li}^{+}$, were within permissible limits for all samples. Yet, $2 \%$ of waters contain $\mathrm{NO}_{3}{ }^{-}$at slightly high concentration. The water quality index (WQI) reveals that $94 \%$ of the samples were excellent for drinking (class I). While the remaining was unsuitable due to total coliform group contamination "class (V)". Durov diagram suggest no clear facies and dominant water type can be noted. It indicates mixing processes of two or more different facies might be occurring in the groundwater system. All studied waters were undersaturated with respect to halite, gypsum, fluorite, and anhydrite. These minerals tend to dissolve and increase water salinity. A direct relationship between Zamzam water salinity and rainfall is recorded. The water salinity fluctuated between $4500 \mathrm{mg} \mathrm{L}^{-1}$ (year 1950) and $500 \mathrm{mg} \mathrm{L}^{-1}$ (year 2015) based on rainfall extent. The
\end{abstract}

Electronic supplementary material The online version of this article (doi:10.1007/s13201-017-0549-x) contains supplementary material, which is available to authorized users.

Anwar A. Aly

aaaly@ksu.edu.sa; anwarsiwa@yahoo.com

1 Soil Science Department, College of Food and Agriculture Sciences, King Saud University, Riyadh 11451, Saudi Arabia

2 Food and Drug Authority, Riyadh, Saudi Arabia

3 Soil and Water Science Department, Alexandria University, Alexandria, Egypt approach applied can be used to similar groundwater worldwide.

Keywords Zamzam - Groundwater quality · Water quality index $\cdot$ AquaChem software

\section{Introduction}

It is unnecessary to say that the quality of water is the most significant concerns of human health, especially in arid environment (Al-Omran et al. 2012). Sometime, humans have to use water contaminated by disease vectors, pathogens, or improper concentrations of toxins (William and Frank 2000). Using this water may lead to various diseases and sometimes death. Monitoring drinking groundwater is essential to confirm its safety (USEPA 2007). The hydrochemical and microbial analyses of groundwater have a substantial role in assessing water quality (Tiwari 2011). Countless people drink Zamzam groundwater in Saudi Arabia (Shomar 2012). According to Arab historians, the Zamzam well has been in use for around 4000 years (Khalid et al. 2014). The major solute chemistry reveals that the water contains high concentration of calcium and its water type is calcium carbonate type. The water is alkaline and the distributions of major salts are: magnesium bicarbonate, magnesium sulfate, sodium and potassium chloride (Shomar 2012; Al-Gamal 2009). The long residence time with aquifer materials of basic lava origin (basalt) led to the formation of ferro-magnesium minerals, soluble calcium and magnesium, in water (Al-Gamal 2009). Shomar (2012) reported that the Zamzam water contains high concentration of As and $\mathrm{NO}_{3}$ and set above permission limit of WHO; on the other hand, Al Nouri et al. (2014) 
reported that the Zamzam water is free of As contaminations and its concentration sets within permissible limits according to WHO (2011) and SASO (1984). Griffin et al. (2007) reported that the Zamzam water contains high concentration of Fluoride and some other element. Mashat (2010) reported that the Zamzam water has no sign of biological growth due to it is naturally pure and salt-sterilized contents. In 1971, the ministry of agriculture and water resources sent Zamzam water samples to the European laboratories to test its potability. The results indicated that the water can be considered suitable for drinking; nevertheless, it contains slightly high concentration of fluoride, calcium, and magnesium (The annual report of the ministry of agriculture and water resources 1971). Calcium and magnesium in water and food are known to have antitoxic activity. They can help prevent the absorption of some toxic elements such as lead and cadmium from the intestine into the blood, either via direct reaction leading to formation of a non-absorbable compound or via competition for binding sites (Kozisek 2004). In addition, the WHO (1980) concluded that the populations supplied with low-mineral water may be at a higher risk in terms of adverse effects from exposure to toxic substances compared to populations supplied with water containing adequate mineral and hardness. Furthermore, the low mineral water and low TDS may cause salts to be leached from the human body. Shomar (2012) reported that the top $14 \mathrm{~m}$ of the Zamzam well is excavated in the sandy alluvium of the Wadi Ibrahim; however, the lower $17 \mathrm{~m}$ is located in the diorite bedrock. A 0.5 -m-thick highly permeable weathered rock located between the alluvium and bedrock was observed. Most of the alluvial section of the well is lined with stone except for the uppermost $1 \mathrm{~m}$, which has a reinforced concrete collar. The water enters to Zamzam well from alluvial section and at depth $13 \mathrm{~m}$ from surface. In attempting to test the well flow rate, a pumping machine at $8000 \mathrm{~L} \mathrm{~s}^{-1}$ was operated for more than $24 \mathrm{~h}$. This test showed a decrease in the level of water by about $10 \mathrm{~m}$ and then the water level stopped receding. The water level recovered to its approximately original surface just after 11 min after pumping had stopped (ZSRC 2011). The aquifer feeding the Zamzam well appears to recharge from rock fractures in adjacent mountains around Mecca (Makkah). Therefore, the well taps groundwater primarily from the spring-fed alluvium and to a lesser extent from water percolating up through the permeable, weathered fresh bedrock (ZSRC 2011). This study aims to investigate the chemical and microbiological composition of Zamzam water, assess Zamzam waters for drinking purposes, and finally classify the hydrochemical characterization of Zamzam well.

\section{Materials and methods}

\section{Study area}

Mecca city is located in western part of Saudi Arabia about $70 \mathrm{~km}$ to the south of the city of Jeddah on the coast of the Red Sea. Mecca is bound by latitudes $21^{\circ} 26^{\prime} 48^{\prime \prime} \mathrm{N}$ and longitudes $39^{\circ} 53^{\prime} 46^{\prime \prime} \mathrm{E}$ with an elevation of about $+1399 \mathrm{ft}$ (Al-Gamal 2009) (Fig. 1). The city of Mecca contains AlMsgied Alharam. The Ka'ba Amosharafa is located inside the Alharam and Zamzam well located at about 20 m east of the Ka'ba (Fig. 2) (Koshak 1983). Al-Gamal (2009) recorded that the recharge of Zamzam well may have occurred during the last Holocene humid period and that the aquifer is now discharging ancient groundwater resources.

\section{Chemical and microbiological analysis}

Fifty water samples were collected from different locations in Saudi Arabia (Supplementary Table 1). Three samples were collected from the original well in Mecca, 13 samples from taps connected to the original well, ten samples from ice box filled with Zamzam water inside and outside Alharam in Mecca, three samples from Zamzam bottled Water Company in Mecca, 15 samples from Al-Madenah Almonawara, and six samples from Riyadh city. The Zamzam waters of Al-Madenah were transported from Mecca by government; however, Riyadh Zamzam waters were transported from bottled water company in Mecca by traders and sold in supermarkets and food stores in Riyadh. All samples were gathered, stored in ice box, and transported to King Saud University labs for analyses.

\section{Microbiological analysis}

Several microbiological estimations were conducted in this study, including the total colony counts, total coliform group, and E. coli. The total numbers of colony were determined by nutrient agar method; however, the coliform group and E. coli were determined by Colilert (defined substrate) method as described by Eckner (1998) and Maheux et al. (2008).

\section{Chemical analysis}

The water electrical conductivity (EC) in $\mathrm{dS} \mathrm{m}^{-1}$ was measured using EC meter at $25{ }^{\circ} \mathrm{C}$ (Test kit Model 1500-20, Cole and Parmer); however, the $\mathrm{pH}$ was measured by $\mathrm{pH}$ meters (CG 817) (APHA 1998). In Addition, calcium $\left(\mathrm{Ca}^{2+}\right)$, magnesium $\left(\mathrm{Mg}^{2+}\right)$, sodium $\left(\mathrm{Na}^{+}\right)$, lithium $\left(\mathrm{Li}^{+}\right)$, potassium $\left(\mathrm{K}^{+}\right)$, ammonium $\left(\mathrm{NH}_{4}{ }^{+}\right)$, fluoride $\left(\mathrm{F}^{-}\right)$, bromide 


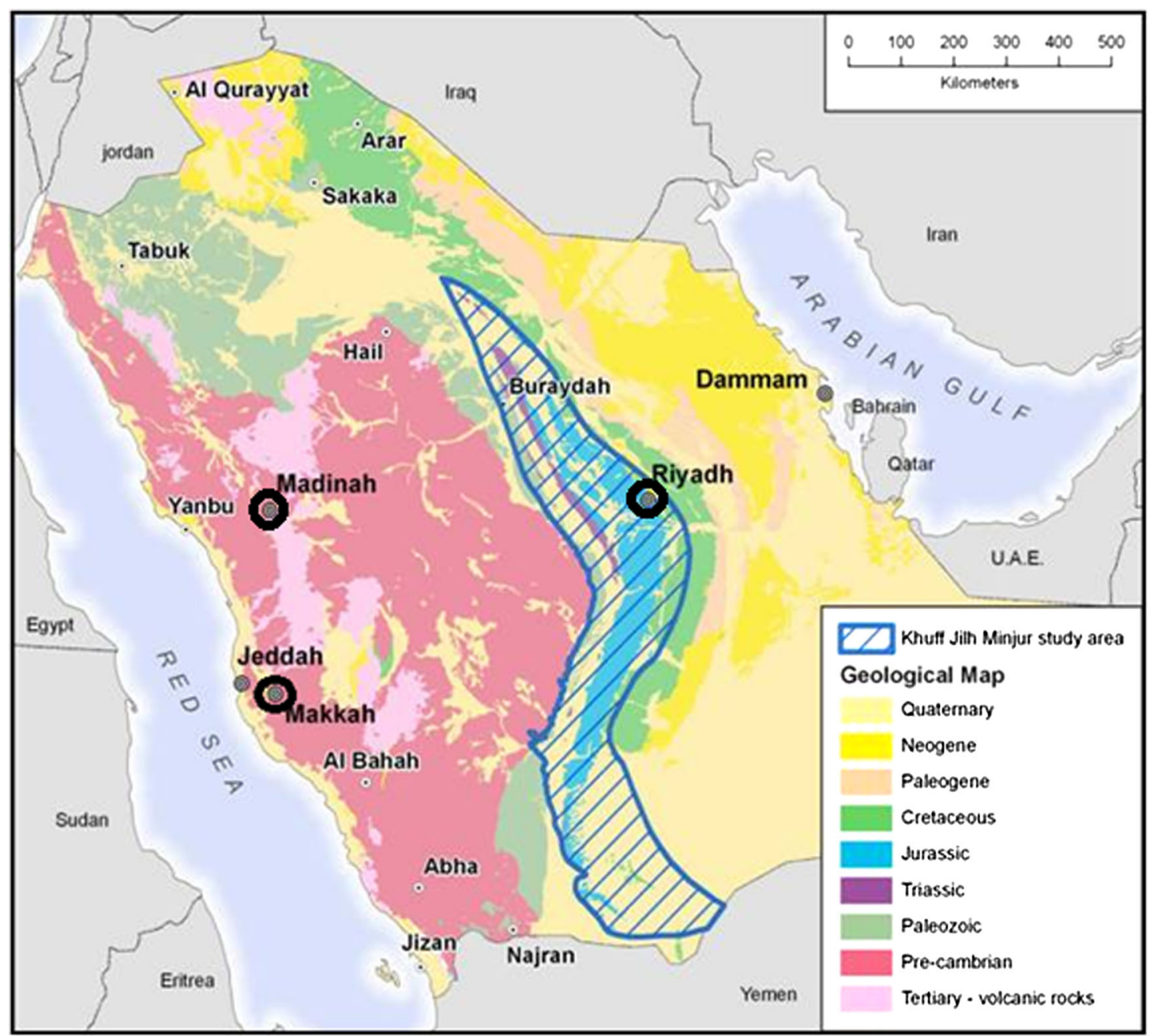

Fig. 1 Geological map of Saudi Arabia showing the locations of sampling Zamzam waters in Makkah (Mecca) Alocarama, Madinah Almoawara, and Riyadh city (The original well is located in Mecca)

$\left(\mathrm{Br}^{-}\right)$, chloride $\left(\mathrm{Cl}^{-}\right)$, sulfate $\left(\mathrm{SO}_{4}{ }^{2-}\right)$, phosphate $\left(\mathrm{PO}_{4}{ }^{3-}\right)$, nitrate $\left(\mathrm{NO}_{3}{ }^{-}\right)$, and nitrite $\left(\mathrm{NO}_{2}{ }^{-}\right)$were determined using ion chromatography system (ICS 5000, Thermo (USA)). The arsenic (As), cadmium (Cd), cobalt (Co), chromium $(\mathrm{Cr})$, copper $(\mathrm{Cu})$, iron $(\mathrm{Fe})$, manganese $(\mathrm{Mn})$, nickel $(\mathrm{Ni})$, lead $(\mathrm{Pb})$, and zinc $(\mathrm{Zn})$ were measured using ICP-Perkin Elmer Model 4300DV. Furthermore, carbonate $\left(\mathrm{CO}_{3}{ }^{2-}\right)$ and bicarbonate $\left(\mathrm{HCO}_{3}{ }^{-}\right)$were determined by titration with sulfuric acid $\left(\mathrm{H}_{2} \mathrm{SO}_{4}\right)$ (Matiti 2004).

\section{Standards and chemicals}

Dionex combined cation standard and anion standard solutions and PerkinElmer quality control multi-element standards were purchased and used as a stock standard for preparing working standards of ICS and ICP, respectively. All solutions were stored in precleaned high-density polyethylene (HDPE) bottles and refrigerated at $4{ }^{\circ} \mathrm{C}$. The working standards were prepared by serial volume/volume dilution in polypropylene vials (Sarstedt, Germany). Micropipettes (Eppendorf, Sigma-Aldrich) with disposable tips were used for pipetting all solutions. High-purity water (18.2 M $\Omega)$ was prepared using a Millipore ion-exchange system fed with deionized water (US filter).

\section{Ion balance errors}

The accuracy of chemical analysis was confirmed by calculating ion balance errors; moreover, blanks and standard solutions were frequently run to check for probable errors in the analytical processes. The error level in the data was calculated by the following method (Appelo and Postma 1996):

Error of ion balance $=\frac{\sum \text { cations }-\sum \text { anions }}{\sum \text { cations }+\sum \text { anions }} \times 100$.

An error of up to $\pm 3 \%$ is tolerable, while every water sample with a calculated error outside this range has to be 


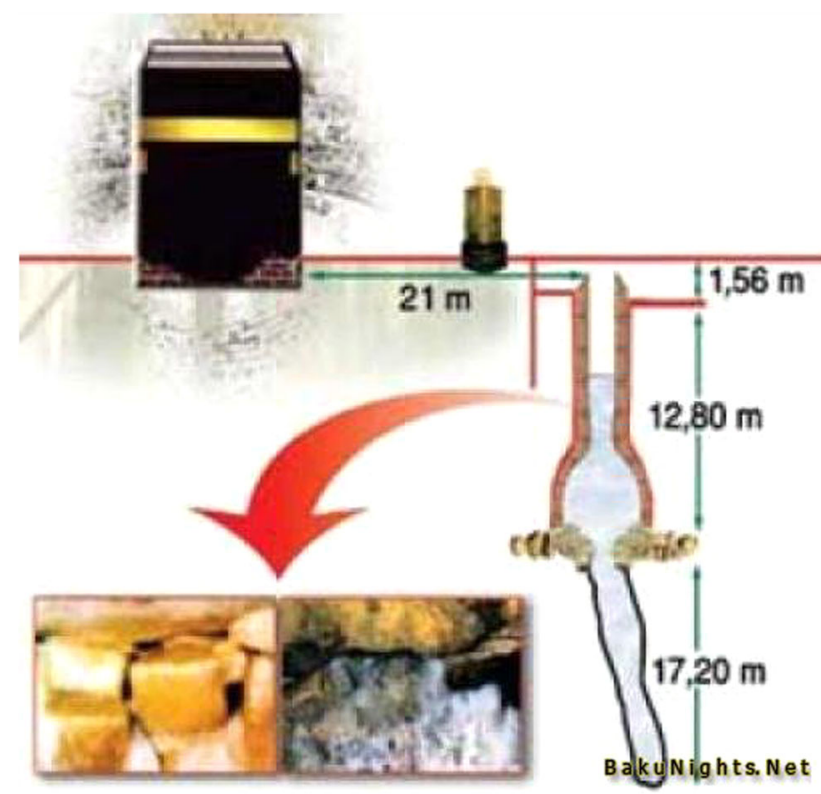

Fig. 2 Depth and location of Zamzam well near to Ka'ba Amosharafa (ZSRC 2011)

re-measured. Approximately $95 \%$ of the measured water samples were fall within this range. This means that the resultant data qualities are sufficient for chemical modeling and/or for drawing simple conclusions about water quality.

\section{Water quality indices computing}

The water quality index (WQI) calculations include three sequential steps as in Yidana and Yidana (2010), Al-hadithi (2012) and Aly et al. (2015). In this study, minor modification was performed when water contains coliform group and/or E. coli. The water is classified directly without calculation to be unsuitable for drinking (Al-Omran et al. 2015).

The first step is 'assigning weight': each of the 13 parameters, with exception coliform group and/or E. coli, has been assigned a weight (wi), according to its relative importance in the overall drinking water quality as shown in Supplementary Table 2. The most significant parameters gave a weight of 5 and the least significant gave a weight of 1. The coliform group and E. coli gave no weight; however, the water quality changed directly to class $\mathrm{V}$ (water unsuitable for drinking). In this study, the maximum weight of 5 referred to $\mathrm{As}, \mathrm{Cd}, \mathrm{Pb}, \mathrm{NO}_{3}, \mathrm{NO}_{2}$, and total counts; due to its adverse effect on water quality assessment (Ramakrishnalah et al. 2009), the less harmful elements, i.e., Fe, $\mathrm{Zn}$, and $\mathrm{Mn}$ have been given a weight of 1 .

The second step is the 'relative weight calculation': the relative weight (Wi) is computed from the following equation:

$\mathrm{Wi}=\frac{\mathrm{wi}}{\sum_{i=1}^{n} \mathrm{wi}}$,

where $\mathrm{Wi}$ is the relative weight, wi is the weight of each parameter, and $n$ is the parameters number. The calculated relative weight (Wi) values of each parameter are given in Supplementary Table 2.

The third step is 'quality rating scale calculation': the quality rating scale (qi) for each parameter is calculated as follows:

$\mathrm{qi}=\frac{\mathrm{Ci}}{\mathrm{Si}} \times 100$,

where qi is the quality rating, $\mathrm{Ci}$ is the concentration of each chemical parameter in each water sample in $\mathrm{mg} \mathrm{L}^{-1}$, except pH, and $\mathrm{Si}$ is the WHO (2011) standard for each chemical parameter (Supplementary Table 2). In this study the WHO standard is adopted since the limits of this standard are the same as the local limits of KSA standard. Finally, Wi and qi are used to calculate the SI $i$ for each chemical parameter, and then the WQI is calculated from the following equation:

$\mathrm{SI} i=\mathrm{Wi} \times \mathrm{qi}$.

$\mathrm{WQI}=\sum_{i=1}^{n} \mathrm{SI} i$,

where SI $i$ is the sub index of each parameter; qi is the rating of each parameter, and $n$ is the parameter number. The calculated WQI values are categorized into five classes (Supplementary Table 3).

\section{Hydrochemical characteristics}

The hydrochemical characterization of the groundwater samples was evaluated by means of major ions, $\mathrm{Ca}^{2+}$, $\mathrm{Mg}^{2+}, \mathrm{Na}^{+}, \mathrm{K}^{+}, \mathrm{HCO}_{3}{ }^{-}, \mathrm{Cl}^{-}$, and $\mathrm{SO}_{4}{ }^{2-}$. The chemical analysis data of the water samples were plotted on the Piper, Schoeller, and Durov diagrams using Geochemistry Software AquaChem 2014.2 for the identification of water types. 


\section{Geochemical modeling}

Interactions between water and the surrounding rocks and soil are considered to be the main processes controlling the observed chemical characteristics of the water. The deviation of water from equilibrium with respect to dissolved minerals is quantitatively described by the saturation index (SI). The SI of a mineral is obtained from the following formula:

$\mathrm{SI}=\log \mathrm{IAP} / k_{t}$,

where IAP is the Ion Activity Product of the dissociated chemical species in solution and $k_{t}$ is the equilibrium solubility product of the chemical involved (Alexakis 2011).

The hydro-geochemical equilibrium model, Phreeqc model (Parkhurst and Appelo 1999), was used to calculate the SI of the groundwater with respect to the main mineral phases.

\section{Results and discussion}

\section{Long-term Zamzam water salinity and rainfall monitoring}

In this study, the Zamzam water salinity is monitored for long-term using our data for the years 2009, 2013 and 2015, and the salinity recorded by Salama (2005), Khalid et al. (2014), American Bedu (2010), and Custodian of the two Holy Mosques Institute for Hajj Research. Furthermore, the long-term water salinity is linked to the rainfall data gathered from WMO (2013) and Dawod et al. (2012) to investigate the impact of rainfall on Zamzam well water salinity (Fig. 3). It was noticed that there is direct relationship between water salinity and rainfall. In world dry period, between 1901 and 1950, the well water salinity increased dramatically to reach $4500 \mathrm{mg} \mathrm{L}^{-1}$; however, it decreased in the wet period (1950-1965) to reach an average of $1800 \mathrm{mg} \mathrm{L}^{-1}$. Since the average rainfall in Mekkah Almokaramah increased from $59 \mathrm{~mm}$ in the period of 1966-1989 to $109 \mathrm{~mm}$ in the period of 1990-2015 (Dawod et al. 2012) (Fig. 3), the water salinity decreased dramatically to reach $500 \mathrm{mg} \mathrm{L}^{-1}$ in the year 2015 . Periodic monitoring seasonally and for long-term of Zamzam well hydrochemistry is recommended for more understanding of the well water chemistry and salinity behavior with rainfall (Aly et al. 2016).

\section{Water quality assessment for drinking purpose}

\section{Microbial assessment}

The results of this study showed that all studied Zamzam waters were free of $E$. coli contamination; moreover, the total colony counts (CFU) fall within the permissible limits for all samples. The USEPA (2009) allow microbial load of $500 \mathrm{CFU} / \mathrm{mL}$; on the other hand, no cell of E. coli permit. Three water samples $(6 \%)$ were found unsuitable due to total coliform contamination. The total coliform groups in the three samples were 689.6, 1986.3, and 1102 (CFU/ $100 \mathrm{~mL}$ ); nevertheless, the remaining $(94 \%)$ have no total coliforms. The samples collected from the main sources were found free of this contamination; consequently, this contamination is caused by an external source as a result of
Fig. 3 Relationship between rainfall of Mekkah and Zamzam water salinity (TDS values of years 1953, 1972, 1973, and 1980 were cited by Salama (2005). TDS values of years 1971, 1975, 1982, 2008 were cited by Khalid et al. (2014). TDS values of years 2010 Posted on 2010 by American Bedu. TDS of years 1979 and 2005 cited by Custodian of the two Holy Mosques Institute for Hajj Research. Rainfall data were cited by Dawod et al. (2012). Asterisk world wet and dry periods were recorded by WMO (2013))
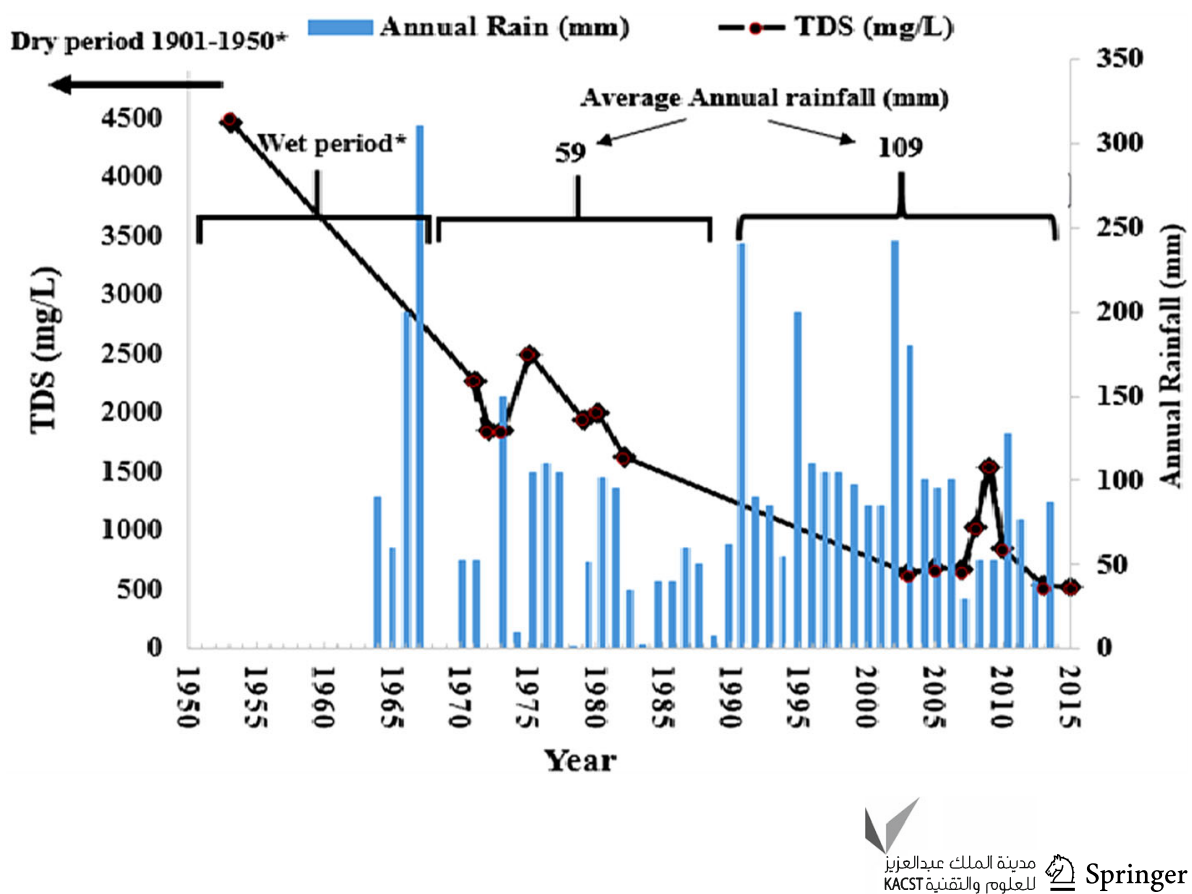
unacceptable human behavior (Al-Omran et al. 2015; AlBarakah et al. 2016) (Supplementary Table 1).

\section{Chemical assessment}

The groundwater's maximum (max), minimum (min), and standard deviation (SD) of the measured parameters was conducted to find out the parameters which differs from the drinking water standards derived by WHO (2011). It was found that the maximum values of most chemical parameters in the studied water were within the permissible limits of the used standard (Al-Omran et al. 2012; Aly et al. 2013). Only one water sample, (the $2 \%$ of the water samples) contains nitrate concentration $\left(52.8 \mathrm{mg} \mathrm{L}^{-1}\right)$ which slightly exceeds the limits given by the literature (WHO 2011; USEPA 2009). Although this study suggests that the Zamzam water salinity was within acceptable limit, most groundwaters in Saudi Arabia are characterized by high salinity (Al-Omran et al. 2012; Aly et al. 2013). The studied groundwater's EC ranged between 0.77 and 0.83 $\mathrm{dS} \mathrm{m}^{-1}$ (SD $\left.= \pm 0.14\right)$; however, the $\mathrm{pH}$ lies in between 7.81 and $8.45(\mathrm{SD}= \pm 0.14)$. The $\max$, min, and (SD) values of $\mathrm{Ca}^{2+}, \mathrm{Mg}^{2+}, \mathrm{Na}^{+}, \mathrm{K}^{+}, \mathrm{CO}_{3}{ }^{2-}, \mathrm{HCO}_{3}{ }^{-}, \mathrm{Cl}^{-}$, and $\mathrm{SO}_{4}{ }^{2-}$ were 2.82-3.78 ( \pm 0.19$), 1.90-2.64 \quad( \pm 0.14)$, 2.92-3.98 ( \pm 0.21$), 0.39-0.70$ ( \pm 0.04$), 0.00-1.60$ ( \pm 0.04$)$, $2.20-4.10( \pm 0.35), 2.86-3.86( \pm 0.13)$, and 2.35-2.94 $( \pm 0.07)$ meq $\mathrm{L}^{-1}$, respectively. Furthermore, the max and min concentrations, and (SD) of $\mathrm{Cr}, \mathrm{Mn}, \mathrm{Fe}, \mathrm{Co}, \mathrm{Ni}, \mathrm{Cu}$, $\mathrm{Zn}, \mathrm{As}, \mathrm{Cd}, \mathrm{Pb}, \mathrm{PO}_{4}{ }^{3-}, \mathrm{NO}_{3}{ }^{-}, \mathrm{NO}_{2}{ }^{-}, \mathrm{Br}^{-}, \mathrm{F}^{-}, \mathrm{NH}_{4}{ }^{+}$, and $\mathrm{Li}^{+}$were 0.092-7.450 ( \pm 1.121$), 0.028-0.632( \pm 0.131)$,

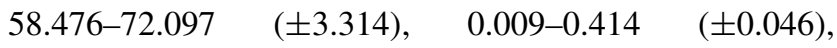

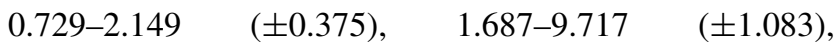
0.000-17.900 ( $( \pm 3.390), \quad 0.006-7.728 \quad( \pm 1.621)$, 0.040-0.113 ( \pm 0.012$), 0.000-0.385$ ( \pm 0.078$), 0.000-0.107$ $( \pm 0.25), \quad 30.00-52.79 \quad( \pm 3.52), \quad 0.00-3.03 \quad( \pm 0.471)$, $0.230-0.685$ ( \pm 0.057$), 0.780-1.590$ ( \pm 0.100$), 0.000-2.489$ $( \pm 0.624)$, and 0.010-0.243 $( \pm 0.069) \mu \mathrm{g} \mathrm{L}^{-1}$, respectively.
The average $\mathrm{Li}^{+}$concentration found in water was $0.184 \mathrm{mg} \mathrm{L}^{-1}$. The $\mathrm{Li}^{+}$is considered a valuable elements when presence in drinking water since it reduced the incidence rates of suicide, homicide, and rape (Schrauzer and Shrestha 1990; Ohgami et al. 2009; Al-Barakah et al. 2016). $\mathrm{F}^{-}$was also found in high concentrations in studied water samples and set within the recommended level of WHO (2011) standard. The mean value of $\mathrm{F}^{-}$in the water is $0.9 \mathrm{mg} \mathrm{L}^{-1}$.

\section{Drinking water quality index}

The computed WQI values for the studied Zamzam waters reveal that $94 \%$ of the water samples were excellent for drinking (class I), and their WQIs were ranged between 28 and 41 with an average of 31 (Fig. 4), Only 6\% were considered unsuitable for drinking "class (V)" due to microbial contamination by total coliforms (Fig. 4) (AlOmran et al. 2015; Deshpande and Aher 2012).

\section{Hydrochemical aspects}

The chemical data of the Zamzam groundwater samples were plotted on a Piper (1944) and Schoeller (1955), diagrams (Figs. 5, 6). The piper diagrams provide a convenient method to classify water types collected from different groundwater resources, based on the ionic composition of different water samples (Aly 2015; Semerjian 2011; Al-Omran et al. 2012; Baba et al. 2008). The main water types have been identified on the basis of the major ion concentrations such as in Aly and Benaabidate (2010) and Aly et al. (2013). The piper diagram reveals that the main water types of the groundwater are $\mathrm{Ca}^{2+}-\mathrm{Mg}^{2+}$ / $\mathrm{SO}_{4}{ }^{2-}-\mathrm{Cl}^{-}$. The water type showed that the geology in the Mecca Almokarama may comprise anhydrite and gypsum. The Schoeller diagram reveals that there is a prevalence of
Fig. 4 Values of WQI of studied samples

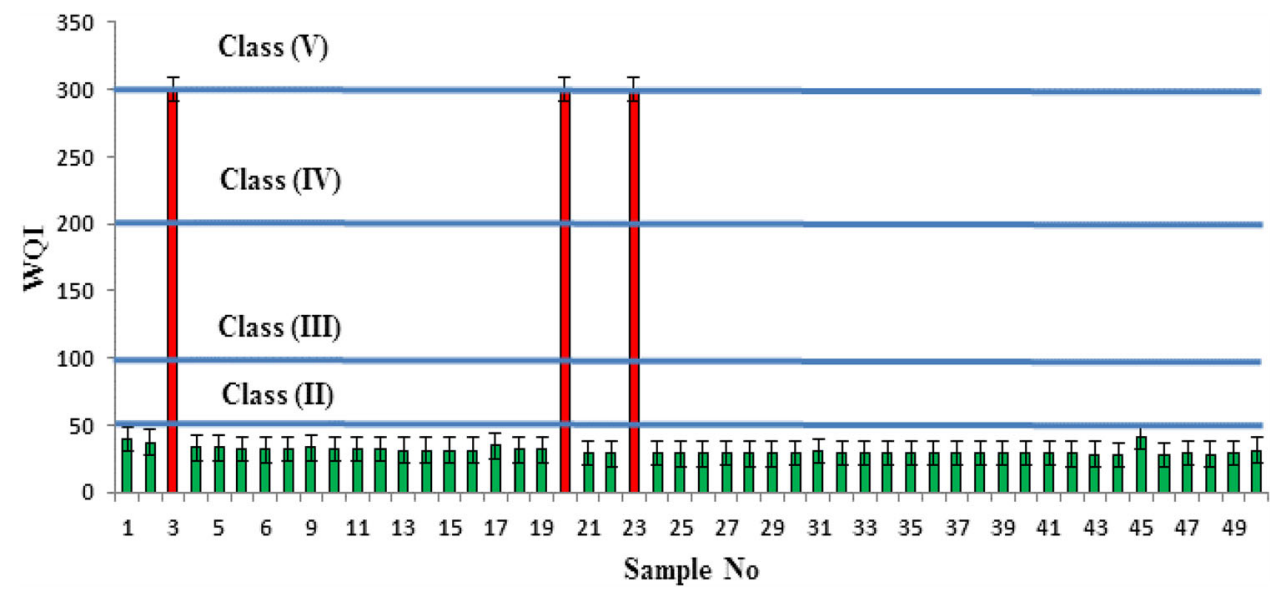




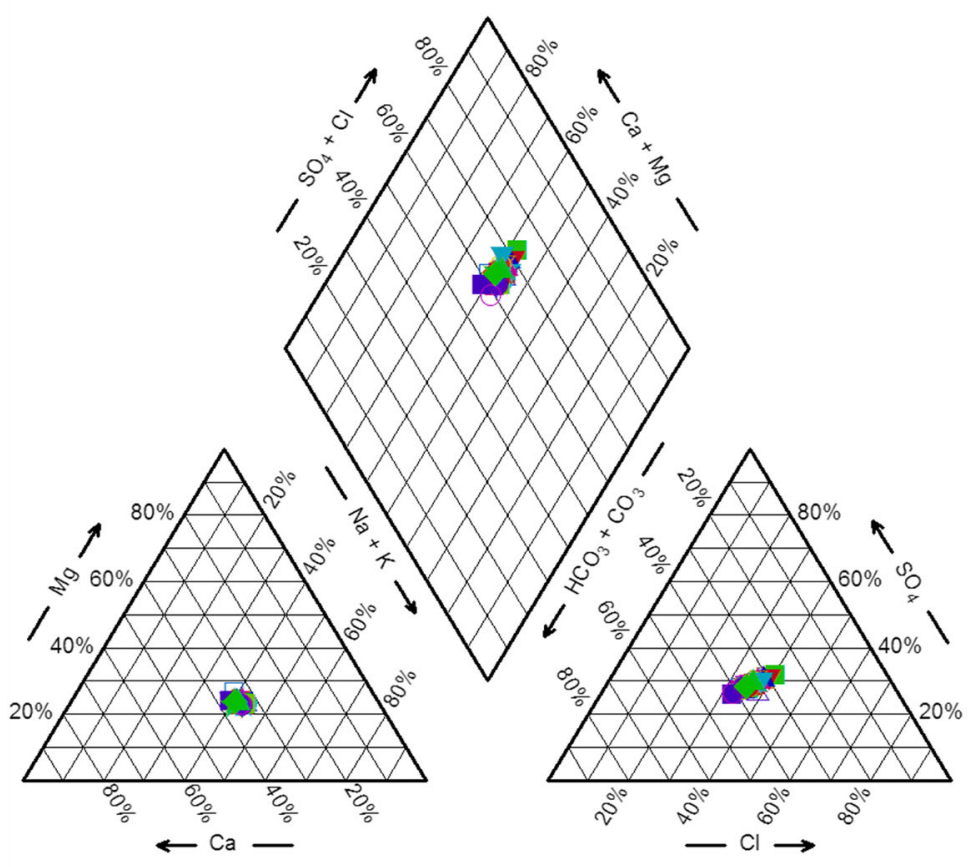

\begin{tabular}{|c|}
\hline Legend \\
\hline$\square 1$ \\
\hline$\Delta 2$ \\
\hline$\triangle 3$ \\
\hline = 4 \\
\hline 85 \\
\hline घ 6 \\
\hline$\nabla 7$ \\
\hline - 8 \\
\hline$\square 9$ \\
\hline - 10 \\
\hline - 11 \\
\hline$\triangle 12$ \\
\hline . 13 \\
\hline A 14 \\
\hline 15 \\
\hline 816 \\
\hline$\star 17$ \\
\hline$\triangle 18$ \\
\hline - 19 \\
\hline$\geq 20$ \\
\hline$\square 21$ \\
\hline$\diamond 22$ \\
\hline 23 \\
\hline 24 \\
\hline$\star 25$ \\
\hline$\square 26$ \\
\hline 24 More... \\
\hline
\end{tabular}

Fig. 5 Piper-tri-linear diagram

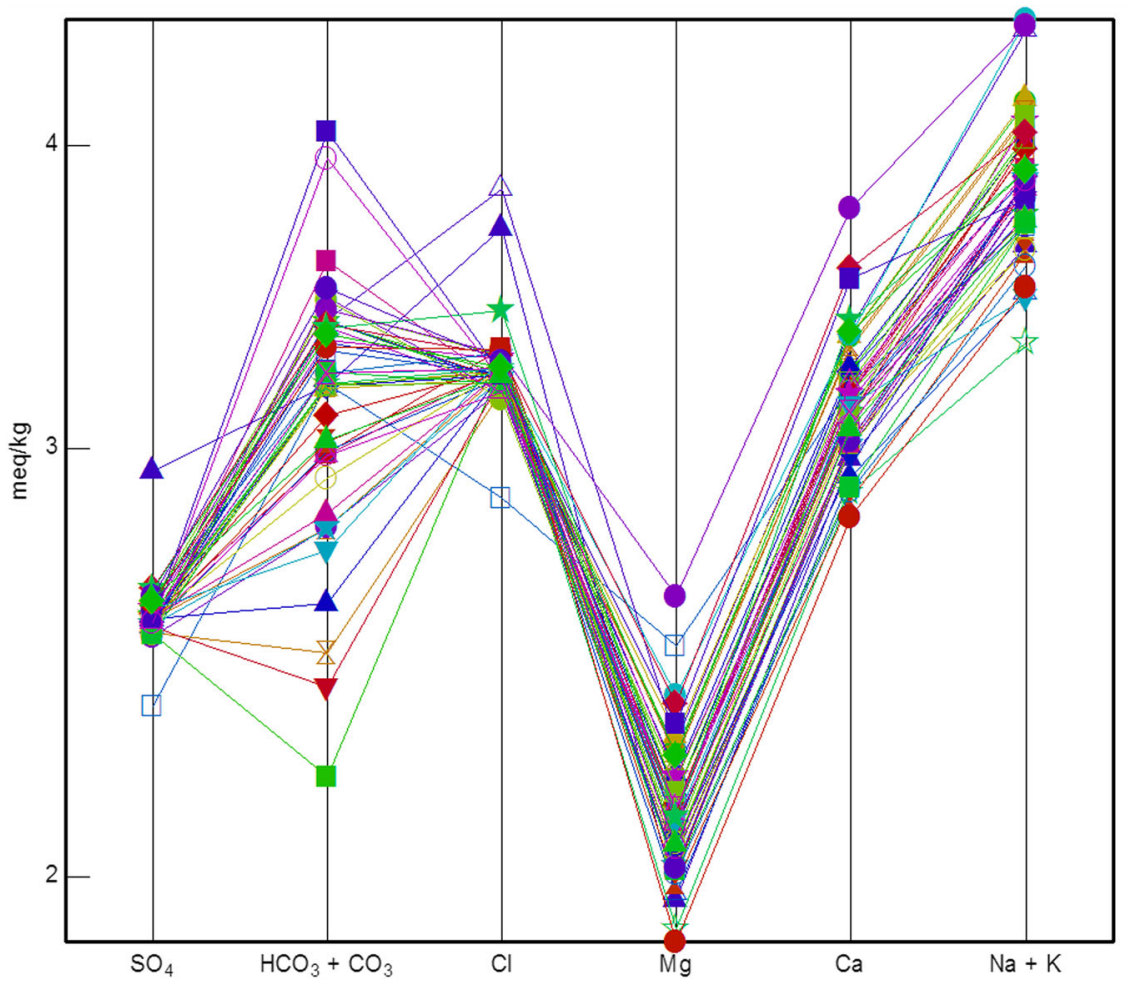

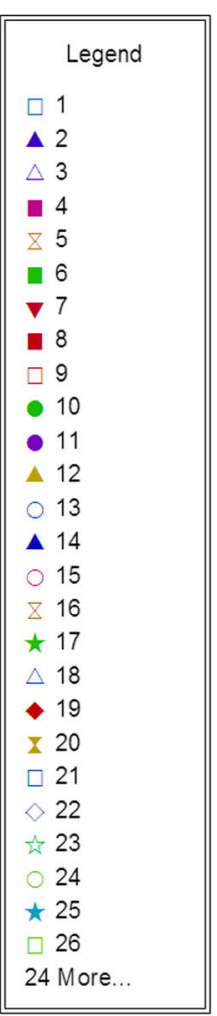

Fig. 6 Schoeller diagram indicating ionic concentrations of groundwater in the study area 
$\mathrm{Ca}^{2+}$ and $\mathrm{Na}^{+}$which influences the affinities to the $\mathrm{HCO}_{3}{ }^{-}, \mathrm{Cl}^{-}$, and $\mathrm{SO}_{4}{ }^{2-}$ (Fig. 6).

The major ions of the studied groundwater were plotted on Durov's diagram (Fig. 7). Durov's diagram helps the interpretation of the evolutionary trends and the hydrochemical processes occurring in the groundwater system and can indicate mixing of different water types, ion exchange, and reverse ion exchange processes. The result shows that all water samples fall in field 5. The samples belonging to field 5 suggest no clear facies and dominant type of water can be noted; furthermore, it demonstrates that mixing of two or more facies might be going on in groundwater system.

Gibbs's diagrams, representing the ratios of $\mathrm{Na}^{+}+\mathrm{K}^{+}$: $\left(\mathrm{Na}^{+}+\mathrm{Ca}^{2+}+\mathrm{Mg}^{2+}\right)$ and $\mathrm{Cl}^{-}:\left(\mathrm{Cl}^{-}+\mathrm{HCO}_{3}{ }^{-}\right)$as a function of TDS, are widely employed to assess the functional sources of dissolved chemical constituents, such as precipitation-dominance, rock-dominance, and evaporation-dominance (Gibbs 1970). The Chemical data of groundwater samples were plotted in Gibbs's diagrams (Fig. 8). The distribution of samples suggests that the chemical weathering of rock-forming minerals is influencing the groundwater quality. The rock domain suggests that rock-water interaction is the major source of dissolved ions over the control of the groundwater chemistry. The rock-water interaction process includes the chemical weathering of rocks, dissolution-precipitation of secondary carbonates, and ion exchange between water and clay minerals (Subba Rao 2006; Kumar et al. 2014).

\section{Salinity and alkalinity hazard class Irrigation}

According to US Salinity Laboratory diagram (Richards 1954) in Fig. 9, the salinity and alkalinity hazard class of water samples is $\mathrm{C} 2-\mathrm{S} 1$. The result shows that all groundwaters possess medium salinity hazards with low sodium hazards. This means that this water is suitable for irrigation to almost all crops with no restriction (Lauchli and Epstein 1990).

\section{Geochemical modeling}

The saturation index (SI) is the parameter generally used for groundwater. Water is in equilibrium with a mineral

\section{Durov Diagram}

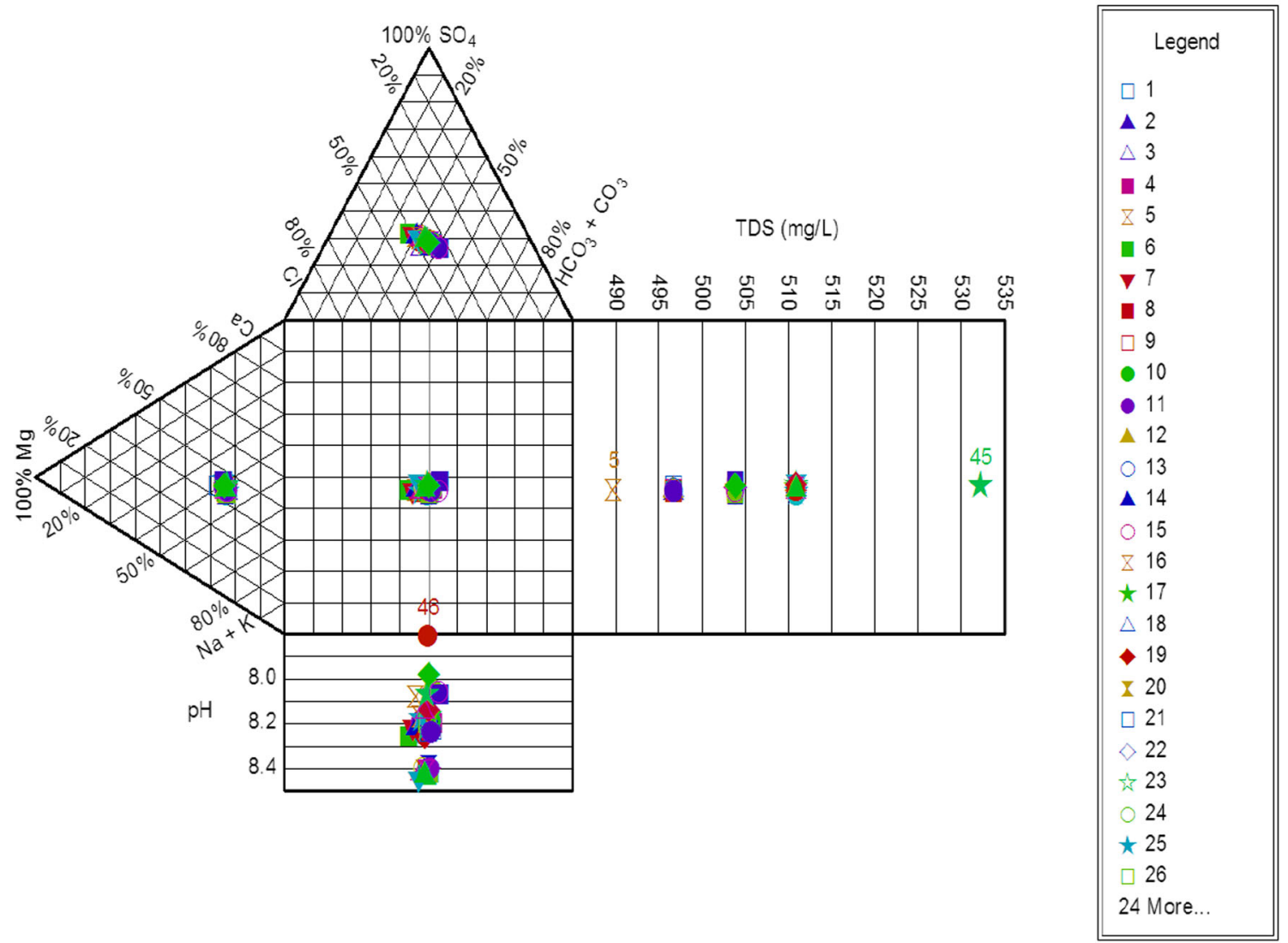

Fig. 7 Durov's diagram for Zamzam groundwater samples: All water fall in field 5 which represents the results of mixing of two or more different facies 

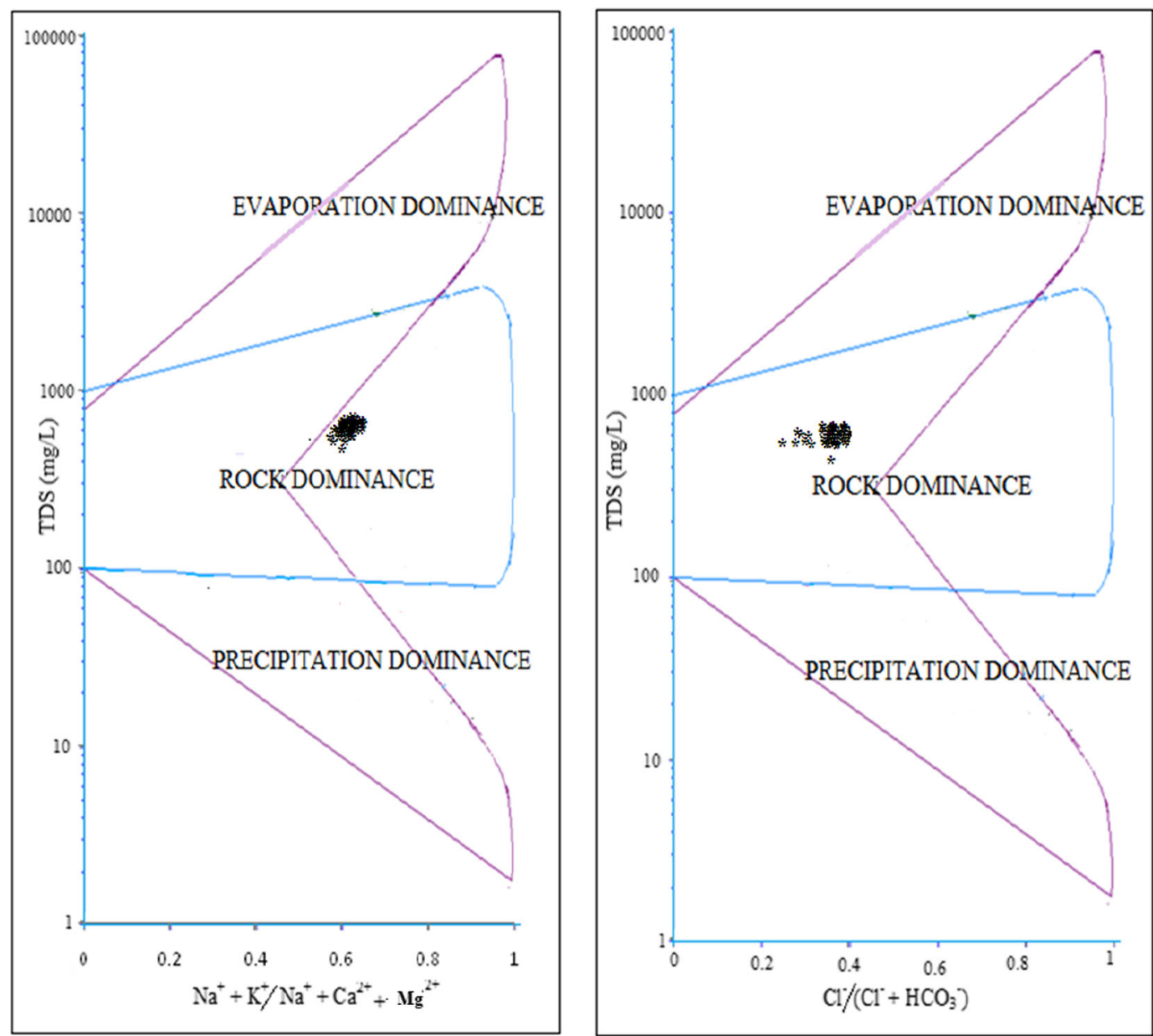

Fig. 8 Diagram depicting the mechanism controlling groundwater quality

when the SI $=$ zero. It is under-saturated if the SI $<$ zero and it is over-saturated when the SI $>$ zero. Nonetheless, to overcome the measurement inaccuracies and changes in the water composition when it makes its way towards the surface, it is proposed to consider a wider range of SI, such as $-1<$ SI $<+1$ (Aly 2015).

Figure $10 \mathrm{a}, \mathrm{b}$ shows the mineral saturation indices (SI) of water calculated by PHREEQC model. The minerals considered by the model were; halite $(\mathrm{NaCl})$, gypsum $\left(\mathrm{CaSO}_{4}: 2 \mathrm{H}_{2} \mathrm{O}\right)$, fluorite $\left(\mathrm{CaF}_{2}\right)$, dolomite $\left(\mathrm{CaMg}\left(\mathrm{CO}_{3}\right)_{2}\right)$, Calcite $\left(\mathrm{CaCO}_{3}\right)$, Aragonite $\left(\mathrm{CaCO}_{3}\right)$, and anhydrite $\left(\mathrm{CaSO}_{4}\right)$. The SI indicated that all investigated waters are undersaturated regarding halite, gypsum, fluorite, and anhydrite. However, they are saturated regarding dolomite, calcite, and aragonite (Fig. 8a, b). Consequently, the halite, gypsum, fluorite, and anhydrite minerals tend to dissolve (Alexakis 2011; Aly 2015). Thus, there is opportunity for more $\mathrm{Na}^{+}, \mathrm{Ca}^{2+}, \mathrm{Cl}^{-}, \mathrm{F}$, and $\mathrm{SO}_{4}{ }^{2-}$ concentration increase in all investigated samples because of the dissolution of these undersaturated minerals.

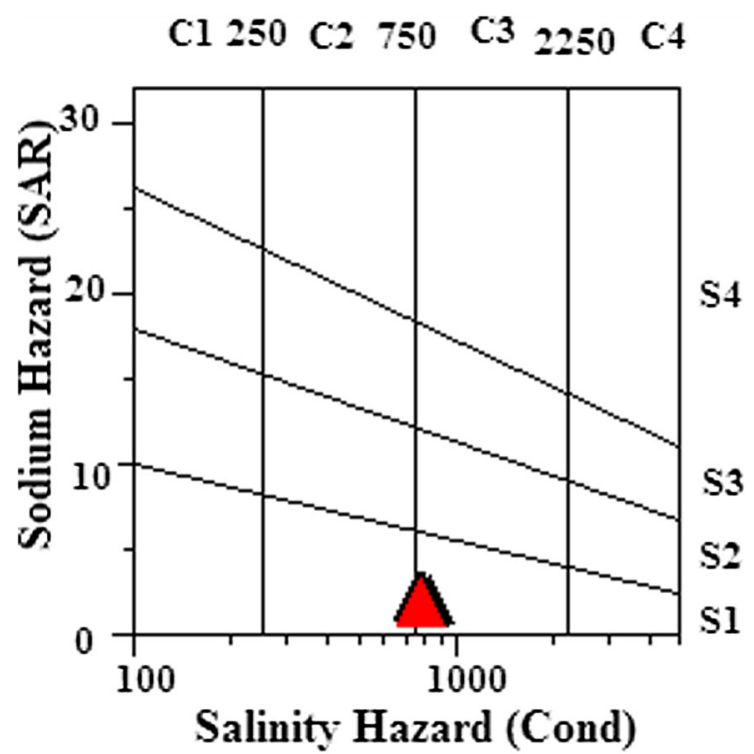

Fig. 9 Salinity classification of Zamzam groundwater if used for irrigation 
Fig. 10 The mineral saturation indices (SI) of gypsum, halite, dolomite, fluorite, aragonite, calcite, and anhydrite
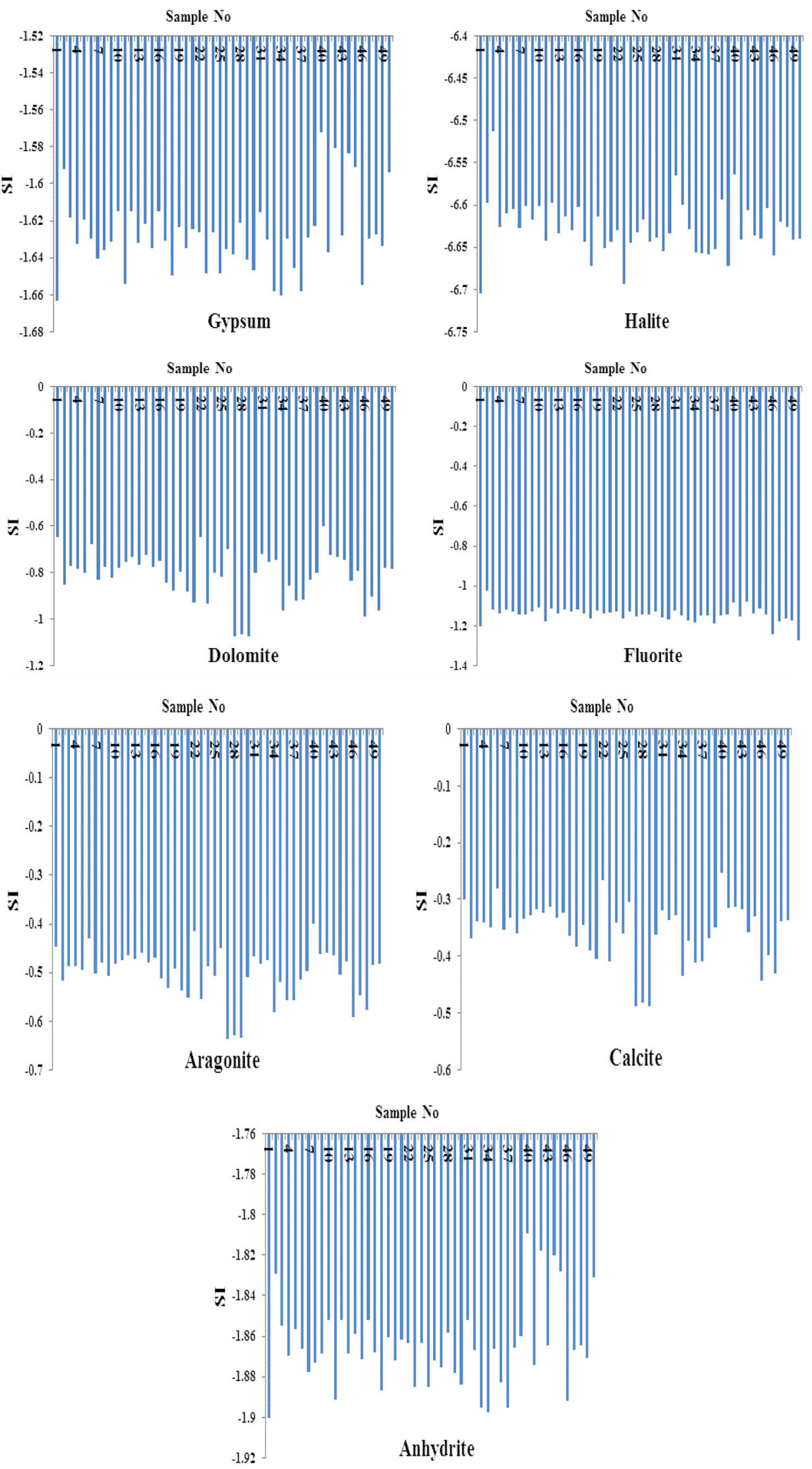


\section{Conclusions}

In this study, a direct relationship between Zamzam groundwater salinity and rainfall is recorded. The distribution of chemical and microbial constituents of the waters were determined and compared with WHO drinking water quality standard. Furthermore, the water quality index (WQI), a mathematical method used to facilitate water quality explanation, was also calculated. The results revealed that the water lies within acceptable limits with respect to dissolved salts, soluble cations and anions, $\mathrm{Pb}, \mathrm{Cd}$, As, $\mathrm{Zn}, \mathrm{Cu}, \mathrm{Ni}, \mathrm{Co}, \mathrm{Fe}, \mathrm{Mn}, \mathrm{Cr}, \mathrm{PO}_{4}{ }^{3-}, \mathrm{NO}_{2}{ }^{-}, \mathrm{Br}^{-}, \mathrm{F}^{-}$, $\mathrm{NH}_{4}^{+}$, and $\mathrm{Li}^{+}$. The nitrate contents of only a small proportion $(2 \%)$ of the water samples were slightly exceeded the corresponding permissible limits. The computed WQI values reveal that $94 \%$ of the water samples were excellent for drinking (class I), and its WQIs were ranged between 28 and 41 with an average of 31 . The remaining water samples were considered unsuitable for drinking "class (V)" due to microbial contamination by total coliforms. The chemical data of the water samples were plotted on Piper, Schoeller, Durov, and Gibbs diagrams. The results concluded that the main water types of the studied well are the following: $\mathrm{Ca}^{2+}$ $\mathrm{Mg}^{2+} / \mathrm{SO}_{4}{ }^{2-}-\mathrm{Cl}^{-}$. The Schoeller diagram reveals that there is a prevalence of $\mathrm{Ca}^{2+}$ and $\mathrm{Na}^{+}$which influences the affinities to the $\mathrm{HCO}_{3}{ }^{-}, \mathrm{Cl}^{-}$, and $\mathrm{SO}_{4}{ }^{2-}$. The Durov's diagram demonstrates that there are mixing processes of two or more different facies that might be occurring in groundwater system. The distribution of samples in Gibbs's diagrams suggests that the chemical weathering of rock-forming minerals is influencing the groundwater quality. The SI indicated that all investigated waters are undersaturated with respect to halite, gypsum, fluorite, and anhydrite. However, they are saturated with respect to dolomite, calcite, and aragonite. Consequently, the undersaturated minerals tend to dissolve and there is an opportunity for more $\mathrm{Na}^{+}, \mathrm{Ca}^{2+}$, $\mathrm{Cl}^{-}, \mathrm{F}$, and $\mathrm{SO}_{4}{ }^{2-}$ concentration increase in the groundwater.

Acknowledgements The authors wish to thank King Saud University, Deanship of Scientific Research, College of Food and Agriculture Science, Research Center for supporting the research work.

Open Access This article is distributed under the terms of the Creative Commons Attribution 4.0 International License (http:// creativecommons.org/licenses/by/4.0/), which permits unrestricted use, distribution, and reproduction in any medium, provided you give appropriate credit to the original author(s) and the source, provide a link to the Creative Commons license, and indicate if changes were made.

\section{References}

Al Nouri D, Al Abdulkarim B, Arzoo S, Nabi Bakeet ZA (2014) Quality characteristics of commonly consumed drinking water in Riyadh and effect of domestic treatments on its chemical constituents. J Food Nutr Res 2(1):25-33. doi:10.12691/jfnr-2-1-

Al-Barakah FN, Al-jassas AM, Aly AA (2016) Nitrate and arsenic concentration status in Zamzam water, Holly Mecca Almocarama, Saudi Arabia. Proc Int Acad Ecol Environ Sci 6(4):110-118

Alexakis D (2011) Assessment of water quality in the MessolonghiEtoliko and Neochorio region (West Greece) using hydrochemical and statistical analysis methods. Environ Monit Assess 182:397-413

Al-Gamal SA (2009) Remarks on the isotopic composition of the holy-water of Zamzam, Mecca area. Environment Magazine 02. http://www.worldenvironment.tv/pdf-mag/we_2.pdf. Accessed on March 2015

Al-hadithi M (2012) Application of water quality index to assess suitability of groundwater quality for drinking purposes in Ratmao-Pathri Rao watershed, Haridwar District India. Am J Sci Ind Res 3(6):395-402. doi:10.5251/ajsir.2012.3.6.395.402

Al-Omran MA, El-Maghraby SE, Aly AA, Al-Wabel IM, Al-Asmari ZA, Nadeem ME (2012) Quality assessment of various bottled waters marketed in Saudi Arabia. Environ Monit Assess 185(8):6397-6406. doi:10.1007/s10661-012-3032-z

Al-Omran A, Al-Barakah F, Altuquq A, Aly A, Nadeem M (2015) Drinking water quality assessment and water quality index of Riyadh, Saudi Arabia. Water Qual Res J Can 50(3):287-296

Aly AA (2015) Hydrochemical characteristics of Egypt western desert oases groundwater. Arab J Geosci 8:7551-7564

Aly AA, Benaabidate L (2010) Salinity of water resources in the Siwa Oasis: monitoring and diagnosis. In: Brikle P, Torres Alvaro IS (eds) Water-rock interaction. Taylor \& Francis Group, London. ISBN 978-0-415-60426-0

Aly AA, Alomran MA, Alwabel M, Almahaini A, Alamari M (2013) Hydrochemical and quality of water resources in Saudi Arabia groundwater: a comparative study of Riyadh and Al-Ahsa regions. Proc Int Acad Ecol Environ Sci 3(1):42-51

Aly AA, Al-Omran AM, Alharby MM (2015) The water quality index and hydrochemical characterization of groundwater resources in Hafar Albatin, Saudi Arabia. Arab J Geosci 8(6):4177-4190. doi:10.1007/s12517-014-1463-2

Aly AA, Gaber HM, Kishk FM, Al-Omran AM (2016) Long-term detection and hydrochemistry of groundwater resources in Siwa Oasis, Egypt. J Saudi Soc Agric Sci 15(1):67-74. doi:10.1016/j. jssas.2014.04.003

American Bedu (2010) Saudi Arabia: What is Zamzam water. Posted on 2 Sept 2010 by American Bedu. http://americanbedu.com/ 2010/09/02/saudi-arabia-what-is-zam-zam-water. Accessed on Dec 2015

APHA (American Public Health Association) (1998) Standard methods for the examination of water and waste water, 20th edn. American Public Health Association, Washington

Appelo CAJ, Postma D (1996) Geochemistry, groundwater and pollution. Balkema AA (ed) Balkema, Rotterdam, Netherlands

Baba A, Erees FS, Hicsonmez U, Cam S, Ozdilek HG (2008) An assessment of the quality of various bottled mineral water marketed in Turkey. Environ Monit Assess 139:277-285

Dawod GM, Mirza MN, Al-Ghamdi KA (2012) GIS-based estimation of flood hazard impacts on road network in Makkah city, Saudi Arabia. Environ Earth Sci 67:2205-2215

Deshpande SM, Aher KR (2012) Evaluation of groundwater quality and its suitability for drinking and agriculture use in parts of Vaijapur, district Aurangabad, MS, India. Res J Chem Sci 2(1):25-31

Eckner KF (1998) Comparison of membrane filtration and multipletube fermentation by the Colilert and Enterolert methods for detection of waterborne Coliform bacteria, Escherchia coli, and Enterococci used in drinking and bating water quality monitoring in Southen Sweden. App Environ Micro 64:3079-3083 
Gibbs RJ (1970) Mechanisms controlling world water chemistry. Science 17:1088-1090

Griffin SO, Regnier E, Griffin PM, Huntley V (2007) Effectiveness of fluoride in preventing caries in adults. J Dent Res 86(5):410-415

Khalid N, Ahmad A, Sumera Khalid S, Ahmed A, Irfan M (2014) Mineral composition and health functionality of Zamzam water: a review. Int J Food Prop 17:661-677

Koshak YH (1983) Zamzam. Dar Alelm for Publications, Jeddah

Kozisek F (2004) Health risks from drinking demineralized water. National Institute of Public Health Czech Republic, pp 148-163. Available online at: http://www.who.int/water_sanitation health/dwq/nutrientschap12.pdf. Accessed on March 2015

Kumar KS, Bharani R, Magesh NS, Godson PS, Chandrasekar N (2014) Hydrogeochemistry and groundwater quality appraisal of part of south Chennai coastal aquifers, Tamil Nadu, India using WQI and fuzzy logic method. Appl Water Sci 4(4):341-350. doi:10.1007/s13201-013-0148-4

Lauchli A, Epstein E (1990) Plant responses to saline and sodic conditions. In: Tanji KK (ed) Agricultural salinity assessment and management. ASCE, New York, pp 113-137 (ASCE manuals and reports on engineering practice No 71)

Maheux AF, Huppé V, Boissinot M, Picard FJ, Bissonnette L, Bernier JL, Bergeron MG (2008) Analytical limits of four betaglucuronidase and beta-galactosidase-based commercial culture methods used to detect Escherichia coli and total coliforms. J Micro Method 75(3):506-514

Mashat BH (2010) The microbiological quality of sabil (free) drinking water in Makkah AlMukarramah. JKAU 21:87-100

Matiti SK (2004) Handbook of methods in environmental studies: water and wastewater analysis. ABD Publishers, Jaipur

Ohgami H, Terao T, Shiotsuki I, Ishii N, Iwata N (2009) Lithium levels in drinking water and risk of suicide. Br J Psychiatry 194:464-465. doi:10.1192/bjp.bp. 108.055798

Parkhurst DL, Appelo CAJ (1999) User's guide to PHREEQC (version 2) - a computer program for speciation, batch-reaction, one-dimensional transport, and inverse geochemical calculations: U.S. Geological Survey: Earth Science Information Center, Open-File Reports Section, USA, p 312

Piper AM (1944) A graphic procedure in the geochemical interpretation of water analysis. Trans Am Geophys Union 25:914-928

Ramakrishnalah CR, Sadas hivalah C, Ranganna G (2009) Assessment of water quality index for the groundwater in Tumkur Taluk, Karnataka state, India. J Chem 6(2):523-530

Richards LA (Ed) (1954) Diagnosis and improvement of saline and alkali soils. USDA Hand book, No. 60, United States Department of Agriculture, USA, p 160

Salama A (2005) Chemical analysis and microbial content of Zamzam water. Zamzam. Book publishing center, Cairo, pp 153-188 (in Arabic)
SASO (Saudi Arabian Standards Organization) (1984) Bottled and unbottled drinking water SSA 409/1984, 2nd edn. SASO information center, Riyadh, pp 1-8

Schoeller H (1955) Géochimie des eaux souterraines. Aplication aux eaux des gisements de pétrole. Inst Français duPétrole, Paris

Schrauzer GN, Shrestha KP (1990) Lithium in drinking water and the incidences of crimes, suicides, and arrests related to drug addictions. Biol Trace Elem Res 25(2):105-118

Semerjian LA (2011) Quality assessment of various bottled waters marketed in Lebanon. Environ Monit Asses 172:275-285

Shomar B (2012) Zamzam water: concentration of trace elements and other characteristics. Chemosphere 86(6):600-605. doi:10.1016/ j.chemosphere

Subba Rao N (2006) Seasonal variation of groundwater quality in a part of Guntur district, Andhra Pradesh, India. Environ Geol 49:413-429

The annual report of the ministry of agriculture and water resources (1971) Analytical report of Zamzam water. Al Hajj research centre in Om Al Qura university (personal communication)

Tiwari RN (2011) Assessment of groundwater quality and pollution potential of Jawa Block Rewa district, Madhya Pradesh, India. Proc Int Acad Ecol Environ Sci 1(3-4):202-212

US Environmental Protection Agency (USEPA) (2007) Dallas TX (2000-05). Chapter 3: Exposure scenario selection. Retrieved 2 Feb 2007. RCRA Delisting Technical Support Document, p 8

US Environmental proyection Agency (USEPA) (2009) Secondary drinking water regulations: guidance for nuisance chemicals. EPA ground water and drinking water, $\mathrm{pp} \mathrm{1-4.} \mathrm{Available} \mathrm{on} \mathrm{line}$ at: http://www.epa.gov/safewater/consumer/2ndstandards.html. Accessed on 2009

WHO (World Health Organization) (1980) Guidelines on health aspects of water desalination. ETS/80.4. World Health Organization, Geneva

WHO (World Health Organization) (2011) Guidelines for drinkingwater quality, 4th edn. World Health Organization, Geneva

William JC, Frank RR (2000) World water vision: making water everybody's business. Tanet Press, UK

WMO (World Meteorological Organization) (2013) The global climate 2001-2010: a decade of climate extremes. WMO No. 1103. Geneva 2, Switzerland .http://library.wmo.int/pmb_ged/ wmo_1103_en.pdf

Yidana SM, Yidana A (2010) Assessing water quality index and multivariate analysis. Environ Earth Sci 59:1461-1473

ZSRC (Zamzam Studies and Research Centre) (2011) Zamzam studies and research centre, Saudi Arabia. http://www.sgs.org.sa/ English/earth/Pages/Zamzam.aspx. Accessed on Jan 2017 